included the arts and social sciences in their benefactions.

The universities in Britain have maintained a high degree of independence in matters of academic planning and general policy. They choose their own students and staff and themselves determine the content of their teaching. Finance and aspects of policy inseparable from finance are rightly the subject of discussion between the universities and the Government. While greater availability of resources at an earlier period would have better enabled the universities to cope with the difficulties that lie immediately ahead, and, in consequence, university initiatives have been restrained, the balance between university freedom and Government control is, broadly speaking, maintained in a satisfactory position.

The Committee also makes recommendations for strengthening the University Grants Committee by the appointment of a full-time deputy chairman.

\title{
DEPTH AND TECTONICS AS FACTORS IN REGIONAL METAMORPHISM
}

$\mathrm{T}$ HE Geological Society of London held the third of its recently instituted series of symposia at the Royal Institution on November 22, with Prof. S. E. Hollingworth, president of the Society, in the chair.

Prof. H. H. Read opened the symposium with "Some Introductory and Cautionary Remarks" in which he pointed out that the pressures concerned in regional metamorphism may not be related to true crustal depth and that it was not always safe to argue that large vertical movements had occurred where minerals known to form at high pressure were exposed at the surface. This topic was taken up later in the discussion when several speakers argued that tectonic pressures might well exceed load pressure during regional metamorphism and that the experimental evidence concerning the pressure at which minerals such as kyanite crystallized was not in conflict with field evidence which suggested that the mineral could develop rather high in the crust.

Prof. Read and Dr. G. A. Chinner both directed attention to the importance of andalusite as a product of regional metamorphism. Prof. Read suggested that metamorphism of Buchan type characterized by andalusite schists might well prove to be more widespread than the Barrovian sequence. Dr. Chinner discussed the application of synthetic data to pelitic rocks, arguing that the $\mathrm{Al}_{2} \mathrm{SiO}_{5}$ polymorphs are ideal as their phase relationships are independent of the bulk composition of a rock. He suggested that the triple point at which kyanite, sillimanite and andalusite coexist lies in the vicinity of $10-11$ kilobars and $500-600^{\circ} \mathrm{C}$., and that is probably the most reliable pressure-temperature indicator available. Dr. Chinner gave a summary of some of the features of the andalusite-sillimanite sequence (Buchan or Abukuma type regional metamorphism), which is often found around metamorphic nodes or 'highs' which develop in a broad sequence of low-grade rock of greenschist or lower amphibolite facies. Gneissic granite or migmatite may occur in the centre of such rocks, examples of which are known from the Abukuma Plateau in Japan, the Cooma and Albury regions of New South Wales and northern Michigan, among other localities. Dr. Chinner suggested that such rocks formed where recrystallization along geothermal gradients of between $15^{\circ} \mathrm{C}$. and $50^{\circ} \mathrm{C}$. per $\mathrm{km}$. had been followed by an abrupt rise in temperature associated with the intrusion of granite or the uprise of 'juvenile' water. Dr. Chinner illustrated his argument with maps of the distribution of kyanite and andalusite in the classic ground in north-east Scotland, where Barrovian and Buchan metamor- phism are developed in neighbouring areas. Dr. Chinner suggested that certain sillimanite rocks in this region had formed after the kyanite and andalus. ite and that these marked an isobaric rise in temperature which led to the development of migmatite. Dr. Chinner also pointed out that stress-developed pressure might have exceeded depth-load pressure where kyanite-sillimanite sequences had developed

Dr. R. A. Howie directed attention to the evidence for directed pressure which Read and Pitcher had provided in their account of the main Donegal granite, around which kyanite-bearing rocks were developed, and also commented on the possible difficulties in using the andalusite-kyanite-sillimanite triple point, since the fields of stability of the three polymorphs were not separated by lines so much as by bands of indifference.

Dr. Howie referred to the way in which certain changes in the composition of common metamorphic minerals threw light on conditions of metamorphism and mentioned his own work on the $\mathrm{Al}_{2} \mathrm{O}_{3}$ content of orthopyroxenes, which, it will be recalled, he had found to be unusually high in certain granulite facies rocks.

Prof. K. C. Dunham mentioned a striking example of metamorphic inversion caused by shearing stress in which rocks of the albite-epidote amphibolite metamorphic facies overlay green-schist facies rocks which in turn passed downwards into unmetamorphosed rocks. It seemed probable that the highest grade rocks of this sequence have formed at very shallow depths.

Dr. J. Haller provided a fascinating account of metamorphic and migmatitic rocks from eastern Greenland. These are exposed on large unweathered surfaces where it is possible to observe and photograph structures which elsewhere can only be recognized after prolonged geological mapping. As a result of this, Dr. Haller has been able to examine a strip $1,400 \mathrm{~km}$. long within the East Greenland Caledonian fold belt. After describing the general structure and the time-sequence of events which occurred in this orogeny, Dr. Haller went on to discuss the large-scale migmatitic structures. He showed that migmatites had developed both in the sedimentary cover and in the underlying pre-Caledonian crystalline basement. Dr. Haller distinguished a number of syntectonic migmatite masses which he classified as regional doming and locally upwelled masses. The regional bodies are circular to oval masses more than $20 \mathrm{~km}$. in diameter, while the smaller masses measure up to a few kilometres across. Among these, Dr. 
Haller had recognized migmatite domes, tongueshaped migmatite bodies, sheets, mushroom-shaped masses and migmatite complexes formed where migmatites of several types coalesce.

Dr. Haller referred to the intimate connexion between migmatization and regional metamorphism and showed that, just as in the Scottish Caledonides, the motamorphic zones cut across the fold structure and that the thermal changes outlasted the deformation of the superstructure.

Prof. B. C. King gave an account of the pattern of metamorphism in central and western Uganda, where in general there is a progressive increase in motamorphism on descending the stratigraphical succession.

There is also, Prof. King showed, a broad corrolation between grade of metamorphism and degree of duformation. A third factor is the proximity of granite. The occurrence of such minerals as cordierite and andalusite and the facts outlined above suggest that the regional metamorphism may well bo of Buchan type, though Prof. King did not specifically state this.

Prof. King provided an especially interesting account of the reactivation of basement rocks during later cycles. $\mathrm{Ho}$ suggested that the fundamontal control of motamorphism was a rise in the geothermal gradient in the central parts of what was originally a basin of deformation and latterly an orogenic belt.

Dr. N. Rast discussed the relationship between deformation and regional metamorphism in the Dalradian rocks of Scotland. He showed that two peaks of regional metamorphism could be identified, the earlier of which accompanied the second of the threo main phases of deformation, while the later uccurred between the second and third folding phases. Dr. Rast suggested that chemical equilibrium may be more readily reached when tectonic movement accompanied metamorphism and that under static conditions, at least in the lower grades of meta. morphism, a very limited migration of material occurs. $\mathrm{He}$ directed attention to the episodic nature of the Dalradian metamorphism and to recent work pointing to comparable polymetamorphism in the Alps and Pyrenees.

Prof. J. Sutton discussed rather similar relationships near the margin of migmatite complexes of Caledonian and Pre-Cambrian age in north-west Scotland. One feature is the patchy development of metamorphic change in the outermost parts of the areas affected. A close relationship between the onset of metamorphism and the local intensity of deformation is observed in both regions which reinforces one of the points made by Dr. Rast. Both the Laxfordian and the Caledonian complexes are bounded by rather sharp transition zones only a few kilometres in width beyond which the pre-existing rocks rotain their old minerals and structuros. Within the complexes a striking feature is the way in which deformation gradually obliterates the discordance between originally cross-cutting structures. Dr. R. W. Rutland described some features of the Caledonian chain in Norway a feature of which is the development of nappes of high-grade crystalline rocks. Dr. J. M. Hancock suggested that examination of the post. orogenic sediments such as the old Red Sandstone might throw light on the controversial question of tho depth of cover during regional metamorphism. As a large number of Fellows of the Society took part in the discussion, a number of contributions have nocessarily been omitted from this summary. J. SUTTON

\section{INDIAN SEMINAR ON AERONAUTICAL SCIENCES}

\begin{abstract}
A SEMINAR in aeronautical sciences was organized by the National Aeronautical Laboratory, Bangalore, under the auspices of the Council of Scientific and Industrial Research (India) and was held during November 27-December 2. The seminar was inaugurated by the Governor of Mysore and presided over by Prof. M. S. Thacker, director-general of the Council of Scientific and Industrial Research.

More than 250 delegates, including twenty delegates from foreign countries, namely, Australia, France, Holland, Japan, the United Kingdom and the United States, attended the seminar. The delegates were welcomed by Dr. P. Nilakantan, director of the National Aeronautical Laboratory. The technical sessions of the seminar covered several fields of aeronautical interest.
\end{abstract}

Indian activity in the field of aviation is mainly concentrated at Bangalore, where Hindustan Aircraft, Ltd., has factories employing 18,000 people. This firm has produced under licence a large number of British-designed aircraft and aero-engines, and the first flight took place recently of the $H F^{-}-24$, a supersonic fighter of the firm's own design.

There is also an excellent Aeronautical Engineering Department, under Prof. Satish Dhawan, at the Indian Institute of Science, Bangalore. This Institute, the director of which is Dr. Bhagavantam, the scientific adviser to the Ministry of Defence, is very interesting to a visitor, as demonstrating the value of an entirely postgraduate teaching and research institution specializing in the basic physical and chemical sciences and their applications.

The numerous defence laboratories in Bangaloro include the Aeronautical Development Establishment under Dr. Mediratta. To all this previously existing aeronautical activity has now been added the important and rapidly developing National Aeronautical Laboratory under the Council for Scientific and Industrial Research. The seminar therefore gave a valuable opportunity to visitors to inspect much of the most important Indian activity in the aeronautical sciences, as well as to hear lectures on thoso subjects.

The session on aviation meteorology was presided over by Dr. P. R. Krishna Rao, director-general of observatories, India. The main topic discussed was wind structure at high altitudes, particularly in and around India, and its influence on air navigation. The session on aircraft structure and materials was presided over by Dr. V. M. Ghatage, deputy general manager, Hindustan Aircraft, Ltd., and was devoted to creep, fatigue and thermal effects. Prof. S. Dhawan, and also Prof. R. Kawamura of the University of Tokyo, presided over the sessions on aerodynamics, and papers on formation and stability of shock waves, hypersonic aerodynamics and approximation in tran. sonic flows were presented. The highlights of the session were major surveys on aerodynamic noise by Prof. M. J. Lighthill, director, Royal Aircraft Estab- 